\title{
The Need of Prose Teaching Material for Instructional Resources
}

\author{
Elyusra \& Dian Susyla \\ FKIP Muhammadiyah University of Bengkulu \\ Yusra.el.261@gmail.com
}

\begin{abstract}
This paper aimed to describe the need for teaching materials of fictional prose aspects of instructional material structure at FKIP Muhammadiyah University of Bengkulu. This description was part of the results of the development research aimed at producing the teaching materials model of Fictional Prose-based ADOR-MEVERLEE (advanced organizer-meaningful verbal learning-elaboration) to actualize the complexity of students' literary competence at FKIP Muhammadiyah University of Bengkulu. The design used was the research and development design, by implementing three main stages. The stages were: theoretical study activities and research, planning, and production. This paper reveals the results of research at the stage of research, namely the requirements analysis phase, namely the needs of students and lecturers with respect to the model of teaching materials Fictional Prose Studies. The teaching materials of the Fictional Prose Study model are prepared by considering six aspects: 1) instructional material structure, 2) language structure, 3) structure of comprehension, 4) display structure, 5) text structure, and 6) stimulation structure. The structure of the instructional material is developed with the characteristics of: 1) Orienting to the objectives of literary learning on the aspects of knowledge, skills, attitudes, and mastery of cognitive strategies, 2) Relevant to students' background, 3) Taking into account the aspects of manners, local wisdom and gender 4) Selective materials, and 5) Covers material types of concepts, principles, procedures, and values.
\end{abstract}

Keywords--teaching materials, study of fiction prose, advanced organizer, meaningful verbal learning, elaboration theory.

\section{INTRODUCTION}

Research and development conducted by Elyusra and Asiyah (2015) produced "Meaningful Learning, Brain Based Learning, Based Learning Model (MPS-BML-BBL) at FKIP Muhammadiyah University of Bengkulu (UMB). Some specific things in MPS-BML-BBL are learning objectives, in the era of KKNI now termed Learning Achievement (CP), in the form of CPL Study Program, CP courses, and sub-CP courses. Achievement Learning subject is related to three aspects of learning objectives, namely attitude aspects, knowledge aspects, and skills aspects. To achieve the above three aspects of learning, it is required the amount of independent learning portion beyond the face-to-face learning schedule. Three of the above will be done if there is a specially developed teaching material that can support it. Therefore, support in the form of teaching materials that are arranged with orientation to conception, principles, and procedure of prose fiction study that enable students to exercise control / freedom of learning is very important.

In addition, some of the thoughts that underlie the need for the development of teaching materials of prose fiction studies are the following. First, study of study or study of prose fiction in FKIP is a learning that must be run to achieve various indicators of success, namely the mastery of fiction prose theory; basic concept of prose fiction study; various approaches to the study of prose fiction with coverage: understanding, principles, methods/steps of work, and systematic writing. The next indicator writes a fictional prose. In addition, the writings of fictional prose studies reported by students must meet the components or aspects of the analysis/decomposition results, interpretation/interpretation results, and evaluation/assessment results, in addition must state the theories and methods used.

Second, the study report that should be made ideally submitted students in written form by taking a style of scientific work, in this case the proceedings of seminars and journal articles. This brings consequences to the necessity of applying the principles of writing, procedurally, requires a process, which not only runs linearly, but also spirals.

Thirdly, various aspects of the study of fictional prose must be presented by students in the tasks they make. Means, the study materials of fictional prose study should be developed with various types of material. Subject material should consist of types of concepts/ definitions, facts, principles, and procedures, so that the course structure is a combination, between conceptual, procedural, and theoretical structure.

Fourth, is characteristic of prose fiction works. The work of fiction prose, whether in the form of short story genre, novelette, let alone novel need big time allocation to enjoy and read / learn it. Thus, the allocation of student learning time should be divided to study the teaching materials in the form of literary works and to study the material in the form of literary knowledge. Therefore, the presence of learning materials of fictional prose studies that can be studied by students with limited time independently is very important. 
There are no teaching materials that deliberately lectured. The use of commercialized materials is less relevant to the course syllabus, lacking the guidance of the study report writing techniques, as well as abstract concepts, principles and procedures are not adequately explained, making it difficult for students who are in the second semester to apply them. Elyusra (2012) revealed found misconceptions of students in learning literature at FKIP UMB using instructional materials in the form of reference books that are commercialized.

Based on the learning objectives to be achieved, the developed MPS-BML-BBL, as well as the characteristics of the study materials of fictional prose, it is necessary to arrange the teaching materials in a certain way in order to meet the needs of students and lecturers. To meet this requirement should be developed with the learning materials meaningful verbal learning model. As an educational psychologist, Ausubel (in Winkel, 2007, p. 404) takes great interest in learning by emphasizing the meaningful elements of learning through language (meaningful verbal learning). Meaningfulness is defined as a combination of verbal information, concepts, rules and principles, when reviewed together. According to Ausubel, meaningful learning is a process of linking new information to relevant concepts contained in a person's cognitive structure. In order for the learning process to produce something meaningful, not absolute students who find themselves all. Learning acceptance can be made meaningful, that is by explaining the relationship between concepts (Dahar, 2011, p. 95).

Optimizing meaningful learning through language can be achieved with advance organize. Joyce, Weil, and Calhoun (2011, p. 281) suggest that the advanced organizers model is interpreted as the initial setting, motivational generation, etc. designed to strengthen the cognitive structure of learners, their knowledge, of particular lessons and how to manage, clarify, and maintain such knowledge well. Ausubel (in Joyce, Weil, and Calhoun, 2011, p. 282) believe there is a parallel between the way subjects are treated and the way people process information in their minds (their cognitive structures). He holds that every academic discipline has a hierarchically administered (and / or design) structure of concepts. The structure of the discipline or cognitive structure in every general discipline are abstract concepts which include more concrete concepts at lower processing stages.

The types of material in the field of study of fictional prose consisting of facts, concepts, principles/rules, and procedures are also as abstract concepts that are difficult to master students. To overcome this also required the development of teaching materials elaborately. The elaboration of abstract concepts in the course "Prose of Fictional Studies" can be done with a variety of presentations. The elaboration of concepts can be done with Merrill (1983) presentation forms, such as a presentation of generality, example, expository and inquisitive, which can also be elaborated with a number of secondary presentations, such as prerequisite elaboration, contextual elaboration, and mnemonic elaboration.

Based on the above description, the problem that will be answered in this paper is how the needs of students and lecturers in FKIP UMB to the teaching materials model of Prose of Fiction Studies. With the model of teaching materials, it is expected that the complexity of students' literature competence can be realized. These competencies include different levels of attitude, knowledge, and skills. In the realm of knowledge, students will have the competence to know, interpret, apply, analyze, assess, and create works of prose fiction. Competence of attitudes that are expected by the students is the attitude of appreciating the prose of fiction of Indonesia literary works, and the skill of communicating the result of the study of fiction prose that he wrote.

\section{METHOD}

This paper was part of the research result of the development of teaching material model of Fictional Prose Study at FKIP Muhammadiyah University of Bengkulu. The research method used is Research and Development (Research and Development). According to Borg \& Gall, "educational research and development (R \& D) is a process used to develop and validate educational products". Referring to Borg \& Gall (1989, p. 626), the product in the context of research and development of this development of model development of teaching materials. "Products are developed to identify specific needs with detailed specifications (Emzir, 2010, p. 263), then, test the effectiveness of the product (Sugiyono, 2008, p. 407). "When completed, the product is field tested and revised until a certain level of initial effectiveness is achieved (Emzir, 2010, p. 263-264).

This type of research was Research and Development (Research and Development). The following chart illustrates the development model used to derive the instructional model developed in this study. The development model is the Borg \& Gall's model (1989, p. 626) which combined with the development model of Jolly Bolitho and Tomlison: 


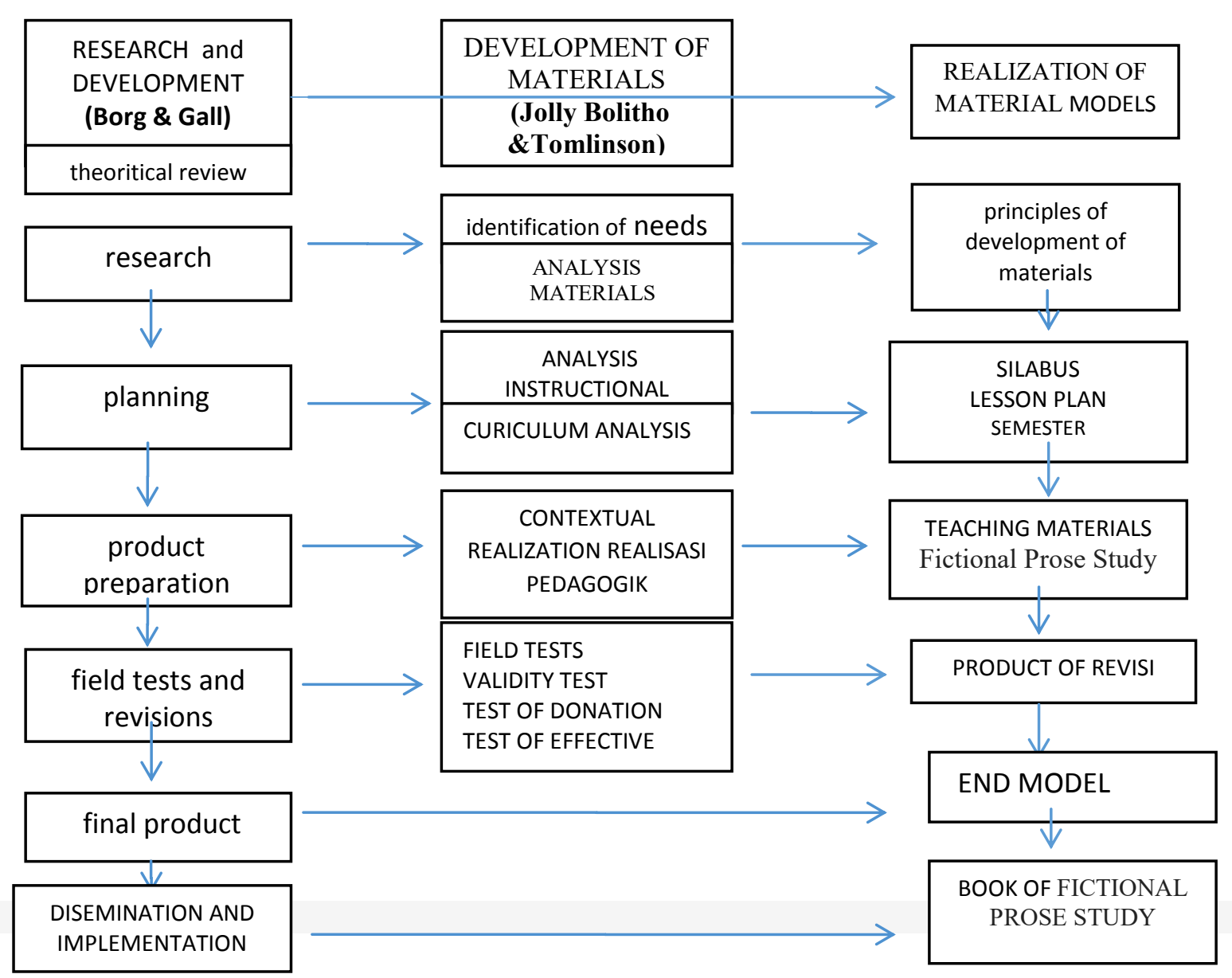

Figure 1: Learning Material Development Framework

The subjects of the study were 100 students and four lecturers of Study of Prose of Fiction subject in Indonesia Language Education and Literature Program of FKIP UMB. Questionnaire instrument was used to obtain the data of students and lecturers' needs. The instrument was developed with the evaluation criteria of teaching materials. The validity of the instrument in term of content validity is obtained through the preparation of the instrument prediction. Questionnaire analysis needs to be developed with seven aspects: 1) perception of the importance of teaching materials, 2) instructional material structure, 3) language structure, 4) structure of comprehension, 5) display structure, 6) text structure / legibility, and 7) stimulants structure. Data were analyzed descriptively.

\section{Students' Needs on Teaching Materials of Fictional Prose Study}

\section{FINDING AND DISCUSSION}

The students' needs of materials are presented in the following table: 
Table 1

Students' Needs on Teaching Materials of Fictional Prose Study

Aspects of Instructional Materials Structure in FKIP UMB

\begin{tabular}{|c|c|c|}
\hline No. & $\begin{array}{l}\text { Structure of } \\
\text { Student Needs }\end{array}$ & Students' Needs \\
\hline 1 & $\begin{array}{l}\text { Perception of } \\
\text { teaching } \\
\text { materials }\end{array}$ & Students perceive the material as very important \\
\hline \multirow[t]{5}{*}{2} & \multirow{5}{*}{$\begin{array}{l}\text { Instructional } \\
\text { Material } \\
\text { Structure }\end{array}$} & $\begin{array}{l}\text { 2.1 Oriented to the objectives of literary learning on aspects of knowledge, } \\
\text { skills, attitudes, and mastery of cognitive strategies. }\end{array}$ \\
\hline & & 2.2 Relevant to student's background \\
\hline & & 2.3 Taking into account the aspect of manners, local wisdom, and gender \\
\hline & & 2.4 Material is selective \\
\hline & & 2.5 Includes the types of material concepts, principles, procedures, and values \\
\hline
\end{tabular}

\section{Lecturers' Needs on Teaching Materials of Fictional Prose Study}

Lecturers' needs on Teaching Materials of Fictional Prose Study obtained from the Tutoring Team which amounted to four people. Seven aspects of lecturers' needs are presented in table 2 below:

Table 2

Lecturers' Needs on Teaching Materials of Fiction Prose Study

Aspects of Instructional Materials Structure in FKIP UMB

\begin{tabular}{llll}
\hline No. & \multicolumn{1}{c}{$\begin{array}{c}\text { Teaching Materials } \\
\text { Structure }\end{array}$} & \multicolumn{1}{c}{ Lecturers' Needs } \\
\hline $\mathbf{1}$ & $\begin{array}{l}\text { Perception of teaching } \\
\text { materials }\end{array}$ & Lecturers perceive the material as very important \\
\hline $\mathbf{2}$ & $\begin{array}{l}\text { Instructional Material } \\
\text { Structure }\end{array}$ & 2.1 & $\begin{array}{l}\text { Oriented to the objectives of literary learning on aspects of knowledge, } \\
\text { skills, attitudes, and mastery of cognitive strategies }\end{array}$ \\
\cline { 2 - 3 } & 2.2 & Relevant to student background \\
\cline { 2 - 3 } & 2.3 & Taking into account the aspect of manners, local wisdom, and gender \\
\cline { 2 - 3 } & 2.4 & Material is selective \\
\cline { 2 - 3 } & 2.5 & $\begin{array}{l}\text { Includes the types of material concepts, principles, procedures, and } \\
\text { values }\end{array}$ \\
\hline
\end{tabular}

The lecturers' needs mentioned above are motivated by lecturer's perception that in term of the sufficiency of available teaching materials, the materials are: less available, not easy to obtain, affordable but less relevant to the purpose. In terms of instructional structure, available instructional materials are: 1) Not relevant to the student's background, 2) Not yet contains aspects of manners, local wisdom, gender, 3) Already compiled with varied sources, 4) Already contains materials of concept, principle, and procedures.

From the questionnaire results, $90 \%$ of students perceive that the teaching materials in the course of Fictional Prose Studies are needed. This is supported by interview data and observation that there is no lecturer who arranged the teaching materials for the study subject of Prose Fiction yet. There are some lecturers who use one book and there are also lecturers who use some commercialized books. The use of a commercial book is not necessarily relevant to the need, while using some books is inefficient and can incriminate students. The lecturer's view data on available teaching materials is that the teaching materials are less available, not easy to obtain, and not relevant to the intended learning objectives.

The needs of students and lecturers to the instructional material structure oriented to the goals of literary learning on aspects of knowledge, skills, attitudes, and mastery of cognitive strategies. The above teaching materials are supported by the data from analyzing available teaching materials. The teaching materials that were analyzed for the purposes of this study were commercialized books, and they were analyzed purposively. The books are: 1) Teori Pengkajian Fiksi by Burhan Nurgiyantoro (1995), 2) Telaah Sastra by Zainuddin Fananie (2000), 3) Pengkajian Sastra by M. Rafiek (2013), 4) 
Analisis Sastra, Teori dan Aplikasi by Dr. I Nyoman Suaka, M.si., 5) Pengkajian Cerita Fiksi by Prof. Dr. Herman J. Waluyo. The analysis of these five books showed different characteristics.

The conclusion from analyzing the five books above are: 1) The books already contain adequate material, 2) The dominant book component is the part of the learning material, 3) The presentation of the samples/models are not equipped with explanation. One book already has a fairly complete component, which includes: a) Basic Competencies, b) Indicators, c) Learning Materials, d) Model/sample studies, e) Conclusions, and Exercises (Nyoman Asaka, 2014). However, based on the results of requirements analysis, these components are not sufficient. In the available teaching materials, the terms Basic Competence and Indicator also need to be adjusted to the terms used in the implementation of KKNI Based Curriculum.

In the available teaching materials, learning aspects of attitude and writing skills of fiction prose studies have not been explicitly stated. Based on the results of instructional analysis conducted on the curriculum of Indonesian Education Study Program developed by the Association of Indonesian Education Studies Program, stated: 1) APS Graduates Profile of Indonesian Education: 1) Beginner Educator1 Indonesian Language and Literature; 2) Beginner Researcher in Indonesian Language and Literature Education Field; 3) Indonesian language and literature entrepreneurs and their lessons; and 4) the initiator of the Indonesian language and literature that is Islamic and has a good character (Team APS Pendidikan Bahasa Indonesia, 2016, p. 4). Achievements of Study Program Graduates (CPL Prodi) as listed in the following table:

Table 3: Study Achievement of Graduates (CPL Prodi)

\begin{tabular}{ccl}
\hline No. & & \multicolumn{1}{c}{ Study Achievement of Graduate } \\
\hline 1 & S5 & $\begin{array}{l}\text { Appreciate cultural diversity, views, religion and beliefs, as well as opinions, or } \\
\text { the original findings of others }\end{array}$ \\
\hline 2 & P1 & $\begin{array}{l}\text { Mastering basic concepts of language and literature, language and literacy skills, } \\
\text { language and literature learning, language and literature research, as well as } \\
\text { research on language and literary education }\end{array}$ \\
\hline 3 & KU1 & $\begin{array}{l}\text { Able to apply logical, critical, systematic, and innovative thinking in the context of } \\
\text { development or implementation of science and technology that concerns and } \\
\text { implements the humanities value of Indonesian language and literature education }\end{array}$ \\
\hline 4 & KU3 & $\begin{array}{l}\text { Able to examine the implications of the development or implementation of the } \\
\text { science of technology that concerns and implements the value of humanities in } \\
\text { Indonesian language and literature education based on scientific rules, procedures, } \\
\text { and ethics in order to produce solutions, ideas, designs or art criticism }\end{array}$ \\
\hline 5 & KK2 & \begin{tabular}{l} 
Able to appreciate, express, create Indonesian literary works and orally \\
\hline
\end{tabular} \\
& Source: (APS Team of Indonesian Education, 2016, p. 4)
\end{tabular}

Further data on student needs on the instructional material structure of Fictional Prose Study is based on eight indicators: 1) goal oriented, 2) relevance to students' background, 3) Taking into account the aspect of manners, local wisdom, gender, 4) learning achievement of knowledge aspect, 5) learning achievement of skill aspect, 6) learning achievement of attitude aspect, 7) cognitive strategy, and 8) material wealth. The data of the students' needs are presented in table 4. 
Table 4: Students' Needs on Teaching Materials of Fictional Prose Study Aspects of Instructional Materials Structure at FKIP University of Muhammadiyah Bengkulu

\begin{tabular}{|c|c|c|c|}
\hline $\begin{array}{l}\text { Materials } \\
\text { Structure }\end{array}$ & Indicator & Sub-Indicator & $\begin{array}{l}\text { Percentage } \\
\text { of Needs }\end{array}$ \\
\hline \multirow{13}{*}{$\begin{array}{l}\text { Instructional } \\
\text { Material Structure }\end{array}$} & \multirow[t]{2}{*}{ 1.1 Oriented to learning } & Strongly required & $60 \%$ \\
\hline & & Required & $40 \%$ \\
\hline & 1.2 Relevant to student background It & Required & $37 \%$ \\
\hline & \multirow{3}{*}{$\begin{array}{l}\text { 1.3 Taking into account the aspect of manners, local } \\
\text { wisdom, gender }\end{array}$} & Manners & $79 \%$ \\
\hline & & Local wisdom & $36 \%$ \\
\hline & & Gender & $32 \%$ \\
\hline & $\begin{array}{l}\text { 1.4 Mastering the knowledge / cognitive field of study } \\
\text { of fiction prose }\end{array}$ & Strongly required & $77 \%$ \\
\hline & 1.5 Have skills to study prose fiction & Required & $44 \%$ \\
\hline & $\begin{array}{l}\text { 1.6 Have a positive attitude towards the study of prose } \\
\text { fiction }\end{array}$ & Required & $20 \%$ \\
\hline & $\begin{array}{l}\text { 1.7 Have the ability of cognitive strategy in studying } \\
\text { fiction prose }\end{array}$ & Strongly required & $65 \%$ \\
\hline & \multirow[t]{3}{*}{ 1.8 Richness / completeness of material type } & Concept & $90 \%$ \\
\hline & & Principle & $37 \%$ \\
\hline & & Procedure & $58 \%$ \\
\hline
\end{tabular}

Based on the data in the table, it can be stated that students need learning materials oriented to the learning objectives in the course that they take. In reality there is a commercialized textbook that has loaded enough material / rich, the presentation is also good, and the price can be reached by students. However, much of the material in the book is not addressed in the course of their course.

The relevance to the student background is only required by $37 \%$ of students. However, all lecturers' teams (100\%) stated the need for conformity of teaching materials with student background. Student backgrounds to note are cultural background, language skills, and age. This is in line with the criteria of literary materials presented by Rahmanto (1988, p. 27) which states: first is language, both mental maturity (psychology), and the third is the cultural background.

In the indicator of integration of values in teaching materials, the value of character, is the most required value of students, by $79 \%$, compared with the value of local wisdom and gender. This number is quite encouraging. Indeed, in essence, literary learning should consider aspects of values. Expressed by Chambers \& Gregory (2006, p. 37), the objectives of literary learning are illustrated in concepts: to give pleasure and enlightenment, self-expression, value, participative, emotional and social development, argument-building and communication skills. Even earlier Horace declared literature to function: dulce et utile, entertaining and giving lessons (Pradopo, 2002, p. 85).

The level of need for integrating the values of local and gender wisdom required students with similar percentage levels, ie $36 \%$ and $32 \%$. For students, the values of local wisdom and gender are not too problematic. However, for Suryaman, et al. (2013, p. 117) attention to gender values in literary textbooks should be given serious attention. It is claimed that literary history books, as well as research articles on literary works, do not yet reflect the existence of gender awareness. Therefore, gender values need to be the basis for the development of literary materials.

Two other aspects that need attention are having the skills to study prose fiction selected as much as $44 \%$ of students and have a positive attitude to the study of prose fiction is selected as much as $20 \%$ of students. This figure is a worrying figure. Students responded to greater goals on the knowledge / cognitive aspect with a figure of $77 \%$. Indeed, in fact this aspect of learning is the safest aspect, the choice of many lecturers and favored students in general.

From the results of interviews with lecturers, aspects of skills and attitudes need to get a balanced portion of the cognitive aspect. This is also in line with the results of the instructional analysis presented above. Thus, teaching materials to be developed should integrate learning aspects of attitudes and skills that are balanced with the cognitive aspects. Abizar (1985) states that knowledge reveals itself to skills. As proof, Anderson and Krathwohl (2001, p. 28) conducted a revision which is an effort to innovate Bloom's taxonomy that has been used in education. They state the dimensions of cognitive processes consisting of: remember, understand, apply, analyze, evaluate, and create.

Another requirement analysis result is having ability of cognitive strategy in studying fiction prose, with tendency equal to $65 \%$. It can be said that quite a wide range of learning skills or metacognitive skills that can be trained or taught to 
students in order to facilitate and accelerate the learning process. Chambers \& Gregory (2006, p. 47) assert that this process should be taught, explicit, comprehensive and in a way that is understandable, interesting. Degeng (1989) also asserted that cognitive strategies are taught in an integrated manner with the presentation of lessons.

Achievements Learning Graduates Prodi Bahasa Indonesia LPTK PTM on aspects of attitudes and values amounted to twelve points. Achievement of skill aspect consists of two categories, namely general skill and special skill, with amount of each of six achievements (APS Team of Pendidikan Bahasa Indonesia, 2016, p. 5-7). Character building at the higher education level was once charged in religious and civic subjects, but since 2010, the character formation of students (students) is charged and required in all courses. Haryadi said that to be able to instill values is by compiling textbooks that are filled with values (2016, p. 285). Even research proves that success in employment is more determined by attitude (Kohl, 2013). The needs of students and lecturers on the structural aspects of instructional materials are further elaborated in the following Sub-CP-MK (Expected Final Ability).

Table 5: Sub-CP-MK (Expected Final Ability)

\begin{tabular}{cl}
\hline No. & \multicolumn{1}{c}{ Sub-CP-Courses } \\
\hline $\mathbf{1}$ & $\begin{array}{l}\text { Appreciate the work of fiction proxies created by Indonesian writers by having them, studying, and } \\
\text { communicating the results of oral and written studies. }\end{array}$ \\
\hline $\mathbf{2}$ & $\begin{array}{l}\text { Able to understand the basic concepts of the nature of prose fiction in the sense / definition of prose fiction, } \\
\text { elements of prose fiction builders, and genre prose fiction }\end{array}$ \\
\hline $\mathbf{3}$ & $\begin{array}{l}\text { Able to understand basic concepts of fiction proxy studies, objectives, scope, aspects, approaches, methods, } \\
\text { and techniques, terms, and variety of writing }\end{array}$ \\
\hline $\mathbf{4}$ & $\begin{array}{l}\text { Able to understand the basic concepts of structural approaches within the framework of prose fiction } \\
\text { studies with the scope: understanding, principles, methods, examples, and systematics of writing the results } \\
\text { of his studies. }\end{array}$ \\
\hline $\mathbf{5}$ & $\begin{array}{l}\text { Able to understand the basic concepts of a stylistic approach in the framework of prose fiction studies with } \\
\text { coverage: assumptions, meanings, objectives, scope, methods, the author's way of creating styles, examples, } \\
\text { and systematics of his study. }\end{array}$ \\
\hline $\mathbf{6}$ & $\begin{array}{l}\text { Able to understand the basic concepts of the approach of literary sociology in the framework of the study of } \\
\text { prose fiction with the scope: understanding, principles, methods, examples, and systematics of writing the } \\
\text { results of his studies. }\end{array}$ \\
\hline $\mathbf{7}$ & $\begin{array}{l}\text { Able to understand the basic concepts of expressive approaches within the framework of prose fiction } \\
\text { studies with the scope: understanding, principles, methods, examples, and systematic writing of the results } \\
\text { of his studies. }\end{array}$ \\
\hline $\mathbf{8}$ & $\begin{array}{l}\text { Able to understand the basic concepts of literary reception approach in the framework of study of fiction } \\
\text { prose with scope: understanding, reader, method, literary function, literary communicative effect, example, } \\
\text { and systematic writing of the result of his study. }\end{array}$ \\
\hline $\mathbf{9}$ & $\begin{array}{l}\text { Able to appreciate Indonesian prose literary works by communicating the results of his studies both orally } \\
\text { and in writing }\end{array}$ \\
\hline
\end{tabular}

The final capability expected in the course of the Fictional Prose Study above is pursued through ten learning materials/subject matters. The materials are: 1) the nature of prose fiction; 2) the nature of the study of prose fiction; 3) study of fiction prose with structural pendants; 4) study of fictional prose with stylistic approach; 5) study of fictional prose with literary sociology approach; 6) study of fiction prose with expressive approach; 7) study of fictional prose with literary reception approach; 8) appreciate the prose of fiction created by the writers of Indonesia; 9) writing fiction prose studies; 10) communicates the results of fictional prose studies.

Through the ten topics, the material is described in the structure of instructional materials required by students and lecturers. With the above ten items, various aspects of learning objectives covering aspects of knowledge, attitude, cognitive strategies, and skills can be achieved. Material number 8 is expected to be able to develop students' positive attitude towards Indonesian fiction prose and its study. The need for aspects of character, local wisdom, and gender can be integrated on various topics. Materials number 9 and 10 are expected to develop student skills in writing fictional prose studies and to communicate it. The mastery of cognitive strategies is studied in an integrated manner in all the materias. With the relevant theoretical orientation of Abrams, it is expected that this material is relevant to the intellectual level of the students and meets the selective nature, and is structured with various types of material in the form of concepts, principles, procedures, and values. 


\section{CONCLUSION AND RECOMMENDATION}

The results showed that the lecturers of the subjects Fictional Prose Study in Indonesia Language Education and Literature Program in FKIP UMB have not developed teaching materials. Students and lecturers expressed great need of teaching materials developed specifically for the subject. Referring to the concept, principles, and procedures of fictional prose study, the instructional material structure of teaching materials needs to be well formulated and implemented in the preparation of teaching materials. The instructional material structure of teaching materials in fictional prose study required by students and lecturers at FKIP UMB has these characteristics 1) Oriented to the purpose of literary learning on aspects of knowledge, skills, attitude, and mastery of cognitive strategy, 2) Relevant to student background, 3) aspects of manners, local wisdom, and gender, 5) Selective materials, 6) Covers material types of concepts, principles, procedures, and values.

The need of students and lecturers above, requires instructional materials in the form of these topics: 1) the nature of prose fiction; 2) the nature of the study of prose fiction; 3) study of fiction prose with structural pendants; 4) study of fictional prose with stylistic approach; 5) study of fictional prose with literary sociology approach; 6) study of fiction prose with expressive approach; 7) study of fictional prose with literary reception approach; 8) appreciate the prose of fiction created by the writers of Indonesia; 9) writing fiction prose studies; 10) communicates the results of fictional prose studies.

The result of this research is the development of teaching materials for Fictional Prose Study based on ADORMAVERLEE, which is considered very urgent. Teaching materials with motivating aspects, exposure of the material with meaningful orientation of verbal learning and elaboration theory are expected to meet the needs of students and lecturers, also able to describe the ten material topics that have been prepared above.

\section{References}

Abizar. (1995). Strategi instruksional. Padang: IKIP Padang Press.

Anderson, L. W. \& Krathwohl D. R.. (2001). A taxonomi for learning, teaching, and assessing: a revision of bloom's taxonomi of educational objectives. New York: Longman.

Borg, W. R. \& Gall M. D. (1989). Educational research: an introduction. New York: Logman.

Chambers, E. \& Gregory, M. (2006). Teaching \& learning english literature. London: I Olivar's Yard.

Dahar, R. W. (2011). Teori- teori belajar \& pembelajaran. Bandung: Erlangga.

Degeng, I. N. S. (1989). Ilmu pengajaran taksonomi variable. Jakarta : Depdikbud.

Elyusra \& Asiyah. (2015). Model pembelajaran sastra berbasis meaningful learning dan brain based learning. Bengkulu: Universitas Muhammadiyah Bengkulu.

Emzir. (2010). Metodologi penelitian pendidikan: kuantitatif \& kualitatif. Jakarta: Raja Grasindo Persada.

Haryadi. (2016). "Buku Ajar Membaca Bermuatan Pendidikan Karakter bagi mahasiswa Pendidikan Bahasa dan sastra Indonesia" dalam Prosiding Seminar Nasional Pertemuan Ilmiah Bahasa dan Sastra Indonesia (PIBSI) XXXVIII, Sukoharjo: UNIVED Press

Joyce, B., Weil, M., and E. Calhoun. (2011). Models of teaching. Terjemahan Acmad Fawaid dan Atailla Mirza. Yogyakarta: Pustaka Pelajar.

Kohl, D. (2013). “Attitude: A characteristic for success” Informa.

Merrill, M.D. (1983). “Component Display Theory” dalam C.M. Reigeluth (Ed). Instructional-Design Theories and Models: An Overview of Their Current Status. Hillsdale, N.J : Lawrence Erlbaum Associates.

Pradopo, R. D. (2001). Kritik sastra indonesia modern. Yogyakarta: Gama Media.

Rahmanto, B. (1988). Metode pengajaran sastra. Yogyakarta: Kanisius.

Suaka, N. (2014). Analisis sastra, teori dan aplikasi. Yogyakarta: Penerbit Ombak.

Suryaman, M., Wiyatmi, Nurhadi, \& E. Liliani. (2013). "Pengembangan Model Buku Ajar Sejarah Sastra Indonesia Modern Berperspektif Gender” LITERA, Jurnal Penelitian Bahasa, Sastra, dan Pengajarannya, Volume 12, Nomor 1, April 2013.

Tim APS Pendidikan Bahasa Indonesia. (2016). Rumusan profil lulusan dan capaian pembelajaran. Surakarta: Tim APS Pendidikan Bahasa Indonesia.

Winkel, W. S. (2007). Psikologi pengajaran. Yogyakarta: Media Abadi. 